\title{
Syntax in the Earliest Latin-Portuguese Grammatical Treatises
}

\author{
Gonçalo Fernandes \\ Universidade de Trás-os-Montes e Alto Douro
}

\section{Introduction}

The authoritative textbooks of Latin grammar used in Portugal in the Middle Ages were largely the same as in the rest of the Western Europe, namely Donatus's (mid-4th cent.) Ars minor, Alexander of Villa Dei's (c.1170-c.1250) Doctrinale Puerorum (c.1199), Priscian's Institutiones grammaticae (c.500 A.D.), Peter Helias's (fl.1130/40-d. post 1166) Summa super Priscianum (c.1140), and John of Genoa's Catholicon (c.1286). ${ }^{1}$ Donatus's Ars minor provided the basic framework for the discussion of the eight parts of speech and their morphology, whereas the syntactical theory contained in the last two books (XVI and XVII) of the Institutiones grammaticae of Priscian formed the basis of the medieval discussions on syntax. The study of Priscian's highly theoretical Institutiones grammaticae began to be influenced by Aristotle's logica vetus at the end of the 8th century, when the study of logic was revived in the Carolingian renaissance (see Law 1994, Marenbon 1994, for details). ${ }^{2}$ In the course of the 12th century, new works of Aristotelian philosophy, including the logica noua, the Physics and the Metaphysics, became available and began to influence language theories.

The theory of syntax became a major object of interest among the grammarians in the second half of the 12th century. It is then that the theory of government (regimen) was introduced and developed in close association with Priscian's theory of transitivity, and the functional notions of subject (suppositum) and predicate (appositum) were adopted into grammar from logic (Rosier 1984, 1994; Rosier-Catach

1. The funds of the main Portuguese monasteries, Santa Cruz de Coimbra and Alcobaça, also include manuscripts of grammatici antiqui, such as Donatus and Priscian, and grammatici juniores, such as Isidore of Seville (c.560-636), Papias Vocabulista of Lombardy (fl. c.1050), Alexander of Villa Dei, Evrard of Béthune (d. c.1212) and Hugutio of Pisa (1130/1140-1210).

2. The texts of the logica vetus introduced into use by Alcuin of York included the anonymous Categoriae decem, Boethius's commentary on Aristotle's De interpretatione and Porpyry's Isagoge (Marenbon 1994: 175). 
2010: 200-203). ${ }^{3}$ It is also in the 12th century that a section on syntax began to be incorporated into pedagogical grammars, such as the Grammatica (c.1120) of Hugh of St Victor (c.1090-1141) and the Doctrinale (see Luhtala 2013: 341, for details). It is through such popular textbooks that the syntactical theories developed in the Northern schools also began to influence the Portuguese grammatical tradition.

In Latin-Portuguese grammatical treatises, syntactical issues appear at least from the 14th century onwards, as is attested by the Reglas pera enformarmos os menyos en latin (henceforth: Reglas), which was heavily influenced by Alexander of Villa Dei's Doctrinale. ${ }^{4}$ Some Priscian commentators, such as Peter Helias and Robert Kilwardby (1215-1279), as well as the Spanish grammaticae proverbiandi (15th cent.), had significant influence on the more advanced Portuguese grammars, such as the Hic incipiunt notabilia que fecit cunctis (henceforth: Notabilia).

This article discusses how the medieval Latin-Portuguese grammatical treatises present the most central concepts of syntactical theory, namely concord, government, and transitivity. I have chosen to discuss two treatises preserved in manuscripts and the first printed grammar in Portugal, which represent the study of Latin at three different levels of instruction in Portugal in the late Middle Ages. The Grammatica Pastrane (1497) was used as an elementary textbook at the University of Lisbon. Its author was probably the Spanish Dominican friar Juan de Pastrana (see Lozano Guillén 1995: 188). ${ }^{5}$ The anonymous Reglas was designed for students at the intermediate level of instruction; and the Notabilia ${ }^{6}$ (1427) of

3. For details of the use of the terms 'subject' and 'predicate' in medieval grammar, and their projections in the humanist grammars, see, e.g., Hunt 1980: 105-107; Robins 1980: 234-237; Pérez Rodríguez \& Lozano Guillén 1988: 288-330; Luhtala 1993: 172-173; Fredborg 2014: 221, 228; and Luhtala 2014: 57-59.

4. The Reglas include 54 passages which show influence from the Doctrinale (see mainly Fernandes 2010: 230-233; 2013: 64).

5. He may have been born on the Balearic Islands in the first half of the 15th century (Anselmo 1979/1980: 182). For further speculations on the life and works of Pastrana, see Codoñer (2000).

6. I have adopted the following transcription criteria: I have expanded all abbreviations and brevigraphs, except for the Portuguese indefinite articles/pronouns $\langle$ hũa(s) $\rangle$, <algũa(s) $\rangle$, and $<$ nenhũa(s) $>$, inclusively when they are written with two vowels $<\mathrm{uu}>$, in order to preserve a Portuguese phonetic characteristic which remains in some Northern Portuguese villages; the tilde on Portuguese vowels (ã, ẽ, ĩ, y, õ, and ũ) was preserved as in the original. I have changed into capital letters the graphemes at the beginning of the sentences and in proper names (anthroponyms and toponyms); I have normalized the use of the Ramist letters, not distinguishing between consonantal and vocalic "i" and "u" respectively; I have changed the long (medial or descending) $<\uparrow>$ for the short (terminal or round) $\langle$ s $>$; I have separated the words that were improperly joined and have combined those that were separated; I have corrected the apparent errors of the typographer and the copyist, but I have retained those which seemed to me phonetic 
the Spanish Cistercian friar Juan Rodríguez de Caracena (15th cent.) from the monastery of Santa Maria de Alcobaça (Barreto 1985) directed to the advanced level of instruction.

\section{Reglas pera enformarmos os menỹos en latin}

The Reglas is a booklet with only seven folios (14 pages) of MS Digby 26 (ff. 76r-82v), belonging to the Bodleian Library at the University of Oxford. It was probably written in the last quarter of the 14th century by a Cistercian monk from the Monastery of Alcobaça, Portugal. One of its first owners in England was Thomas Chapleyn (fl.1417), a Cistercian monk at the Rewley Abbey in Oxford. After Chapleyn's death, the manuscript was passed on to the Oxfordian Masters of Arts regent through Thomas Jolyffe (fl.1452-1479; see Fernandes 2010: 227; 2013: 59). The Reglas is divided into chapters without any particular grammatical order, and it lacks a specific chapter on construction; rather it intercalates syntactical rules with morphological items.

The Reglas was largely based on Alexander of Villa Dei's Doctrinale (see Barreto 1988 and Nascimento 1989, for details), and like the Doctrinale, it was probably aimed at students at the intermediate level of instruction (Percival 1997: 249-250). It is one of the pedagogical merits of this textbook that it introduces the elementary rules of the Latin grammar in the vernacular (Portuguese), presenting the examples in both Latin and Romance. ${ }^{7}$ It also occasionally addresses the students directly, by using verbs in the second person: the anonymous author employs such expressions as deues saber or deues a saber "you should know" eight times and once cõue a saber "it is appropriate to know" (Fernandes 2010: 229-230). ${ }^{8}$ The Reglas seems to avoid theoretical issues, which is consistent with its nature as a textbook intended to be used in the early stages of language learning.

variants of the authors; I have changed double $<\mathrm{rr}>$ into single $<\mathrm{r}>$ at the beginning of the words, which is very common in Notabilia; I have also changed the other double consonants into single ones, such as the double <ss > in the word "cassus", and the double <tt $>$ in "nominattiuus"; I have updated the original punctuation in order better to understand the thoughts or the expressions of the authors.

7. Concerning the use of the vernacular in medieval grammars, see Law 2003: 190-209.

8. For the notion of construction in medieval grammar, see, for example, Kneepkens 1990a. 


\subsection{Syntactical concepts}

No proper definitions are used in this treatise, such as we can find for instance in Donatus's Ars minor. The nominal cases are presented in semantic and functional terms using the vernacular, as follows:

Quem faz e quẽ diz é nominatiuo. Cuia a cousa é genitiuo. A quem dam e a quem dizẽ é datiuo. Aquela cousa que homẽ faz e que homẽ diz é acusatiuo. Per quem homẽ chama é vocatiuo. Vnde se homẽ tolhe e onde se departe é ablatiuo, cum proposiçõ ou sem proposiçõ. (Reglas f. 76 r)

One who does and says is nominative. One of whom a thing is, is genitive. He to whom they give and to whom they tell is dative. What one does and says is accusative. He who one calls is vocative. Where one constrains himself and from whence one comes, is ablative, with or without preposition.

There is a remarkable similarity between this rule and that presented in the Arte de Prisciano y Castellano (Spanish National Library of Madrid, MS 10073). ${ }^{9}$ Thus, it seems that there was a continuum between Portuguese and Spanish grammarians and grammatical doctrines.

\subsection{The rules of 'concord'}

Concord or agreement played a significant part in late medieval pedagogical treatises on syntax, as evident in Regulae congruitatum or Regimina, which consisted of a varying number of rules (regulae), ranging from eight to thirty-two. ${ }^{10}$ In the shortest of them, the Generales regule congruitatum puerorum, ${ }^{11}$ five rules of concord are presented, whereas the longer treatises have up to eight rules dealing with agreement; the remaining rules deal mainly with government. The

9. "Quien faze o quien dize nominative caso es. Cuia es la cosa genitivo caso es. A quien damos o a quien dezimos dativo caso es. Lo que damos o lo <que $>$ dezimos acusativo caso es. Por vocativo llamamos. Por ablativo nos departimos" (quoted in Calvo Fernández \& Esparza Torres 1999: 138). However, it is not possible to say who influenced whom, given that both manuscripts are completely different regarding the objectives, methodology, and the majority of the contents, and there is less certainty about the date of the Spanish copy. Calvo Fernández \& Esparza Torres (1999: 136) say that it was probably copied at the end of the 14th century or the beginning of the 15th century, and according to Gómez Moreno (1989: 42) it was written in the 15th century cursive hand.

10. Such late medieval pedagogical treatises have been printed in two facsimile editions: Fundamentum in Tre latinske grammatikker (Pinborg 1979) and Remigius, Schlewig 1486 (Pinborg 1982).

11. See the previous note. This treatise is printed in the Tre latinske grammatikker, F 80-81. 
first three rules of concord became very popular, appearing for instance in the grammatical treatises composed in the 15th century in Italy and England (see Luhtala 2017 and forthcoming for details). ${ }^{12}$ They deal with the relation between the subject and the predicate, that between an adjective and its headword, and that between the relative word and its antecedent. ${ }^{13}$ These three rules are introduced in the first folio of the Reglas, which suggests that they were to be highlighted as central to the treatise.

In the Reglas, only the second and the third of these rules are presented as involving concord, whereas the relation between the subject and the predicate is considered as an instance of government. In the first rule, it is stated that the verb governs the nominative - as in Deus regnat "God reigns". ${ }^{14}$ The technical terms used in describing this relation are the nominative case and the verb, and it is soon specified that a personal verb is at issue; in the Regule treatises the terms subject (suppositum) and predicate (appositum) are regularly used. ${ }^{15}$

The author of the Reglas spells out the basic concepts for the pupils: nouns, pronouns and participles are in the third person, with the exception of the pronouns ego and $t u$ which are in the first and second person, respectively. The distinction between personal and impersonal verbs is then explained: the personal verb varies in three different persons; in the first and second person, the nominative is definite, but in the third it cannot be understood without the nominative being placed before verb. In support of this view, the Reglas quotes a passage from Priscian, according to which the nominative is understood in the verbs, without which the substance could not be signified: "Inest igitur intellectu nominativus in ipsis verbis quo sine substantia significari non poterat" (Inst.gram. XVII.14; GL III: $116.27-117.1)$ :

12. They occur in the works of the Italian Humanists, Nicolaus Perottus (1429-1480) and Sulpitius Verulanus (c. 1440-1506) (Luhtala 2014: 62). For the English grammars, see the following note.

13. The Generales regule congruitatum puerorum additionally discusses the relation between the demonstrative pronoun (hic, ille) and its referent and the interrogative pronoun and its response as concords (F 80-81). Some other medieval pedagogical treatises discuss two further concords, the gender agreement of the partitive and the superlative words governing the genitive (see, for example, the English 'accedence texts' A, B, C, and F, edited in Thomson 1984: 8, 15, 30-31, 49-50).

14. Since the Reglas gives no examples of the three rules, the examples used in the Regule puerorum are supplied in the text, see notes 10 and 11.

15. "Secunda regula congruitatum grammaticalium est ista, quod suppositum et appositum debent conuenire in numero persona and rectitudine casus, ut 'Sortes currit', 'Deus regnat'” (F 80). 
O nominatiuo senpre se rege da pessõa do uerbo se for da primeyra, da primeyra se for da segunda da segũda se for da terceyra da terceyra se rege. Deues saber que todos os nomes e os pronomes e participios son da terceyra pessõa, saluo ego, mei uel mis, que é da primeyra, e tu tui uel tis, que é da segũda, e os vocatiuos que son da segũda [...]. O uerbo pesõal é que se uarya per tres pessõas, assy como amo, amas, amat, e a mester nominatiuo caso ante sy. Pero nas primeyras e nas segũdas pessoãs dos uerbos entẽdesse nominatiuo certo, e determiado, ainda que se lhy nõ ponha per esta regla.

Como se entende entõ per esta regla e na pessoa do uerbo?

Inest igitur nominatiuus intellectu in primis et in secondis personis uerborum sine quo substancia significari non potest. E nas terceyras nõ se entẽde se se non poser. [...] O uerbo enpersonal he que non a se nõ as terceyras persõas, assi como penitet et tedet, miseret et legitur, satur, laniatur, curritur. Estes nõ hã mester nominatiuo, ante sy [...]. (Reglas f. 76rv)

The nominative is always governed by the person of the verb: if it is of the first, it is governed by the first; if it is of the second, by the second; if it is of the third, by the third. You should know that all nouns and pronouns and participles are of the third person, except ego, mei, or mis "I", which are of the first; and $t u$, $t u i$, or tis "you", which are of the second; and the vocatives are of the second [...]. The personal verb is that which varies in three persons, such as amo "I love", amas "you love", ama "he / she loves", and it is necessary to put the nominative case before it. However, in the first and the second persons of the verb one understands the definite and determined nominative even though it is not expressed, by this rule;

Thus, how does one understand using this rule regarding the person of the verb? The nominative is understood in the first and the second persons of the verbs without which the substance cannot be signified. In the third person it is not understood if it is not expressed [...]. The impersonal verb is when there are only the third persons, such as tedet "to annoy", miseret "to have mercy" and legitur "one reads", satur "to be sated", laniatur "to be torn", curritur "one runs". These do not have the nominative before them.

According to the second rule, the concord between the adjective and the substantive involves four accidents: case, gender, number, and government. In the Regulae texts, as in many other medieval texts, the verb conuenire "to agree" and the noun congruitas "agreement" are used, but the Reglas uses neither these terms nor their translations into Portuguese vernacular; it uses the verb similare "to be similar" instead. This may be due to the author's wish to avoid unnecessary technical terminology in a pedagogical grammar. ${ }^{16}$

16. The term consimile "similar" is also used in the Doctrinale (v. 1079-80): "Horum consimiles debet coniungere casus copula, personam dum pertineant ad eandem" "The copula joins similar cases, when they pertain to the same [person]." 
Como se semela o ageytiuo e o sustãtiuo. O ageytivo e o sustãtivo semelhãse en quatro cousas, en caso, e en genero, en numero, e en regimento, quer se ponha quer se entenda. Outrosi cada u ueer remãço de, depos nome seera genitiuo. (ibid., 76r)

How the adjective and the substantive are similar. The adjective and the substantive are similar in four things: in case, gender, number and government; which is either expressed or understood. Furthermore every time it occurs with 'de' ["of"] in Romance, the noun after it will be genitive. Likewise every time it comes after some reason, it will be ablative or genitive, with preposition or without preposition.

The second rule actually involves two aspects of the syntax of nouns, discussed within two distinct rules in the Regule-treatises: firstly, the relationship of concord between a noun and an adjective as, e.g., in albus equus, and the relationship of government between two nouns in phrases, such as equus regis. ${ }^{17}$ The latter type of construction can be identified with the vernacular preposition 'de'. By combining two rules into one the author probably wanted to shorten the grammatical exposition.

According to the third rule, the relative word agrees with its antecedent in three aspects: gender, number, and person. ${ }^{18}$ This rule remains obscure, because the author proceeds to present exceptions to this rule without giving any example of the regular construction, such as Deus regnat qui cunctis imparat "God reigns, who provides for everything" (see n.17); here the relative pronoun qui agrees with its antecedent deus in number, gender, and person. The examples in the Reglas exemplify lack of concord rather than concord and involve demonstrative and possessive rather than relative pronouns. The medieval grammarians had a very broad understanding of relative words, including at least qui, is, hic, suus, and ipse, but qui is missing in the Reglas. Here the author's attempt to simplify his presentation results in obscurity.

Como se o relatiuo e o antecedens deue asemelhar. O relatiuo e o antecedẽs semelhãse en tres cousas, en genero, e en numero, e en pessõa, exete este 'suus, sua, suum'. E no singular pode fazer relaçõ, a o prular assi como dizemos 'estes homeẽs son boõs, seu e este caualo'. E no prular pode fazer relaçõ ao singular assi como dizemos 'este homẽ e boõ, suas son estas capas'. (Reglas, 76r)

17. The first part of the second rule in the Reglas corresponds to the first rule of the Generales regule congruitatum puerorum: "Prima regula congruitatum grammaticalium est ista, quod adiectiuum et suum substantiuum debent conuenire in numero, genere, et casu, ut 'pater meus', 'albus equus'" (F 80); the latter part of the rule in the Reglas corresponds to the seventh rule in the Regule puerorum: "Septima regula congruitatum grammaticalium est ista, quod quando duo nomina substantiua simul conueniunt in una oratione sine coniunctione media tunc alterum debet esse genetiui casus, ut 'equus regis', cappa Sortis'” (F 81).

18. Cf. "Tertia regula congruitatum grammaticalium est ista quod relatiuum et suum antecedens debent conuenire in numero, genere, aliquando in casu, aliquando in persona, ut 'Deus regnat qui cunctis imparat'” (Regule puerorum F 80). 
How the relative and the antecedent must be similar. The relative and the antecedent are similar in three things: in gender and in number and in person, except for suus, sua, suum "his / her / its / their". And in the singular it can relate to the plural, as we say "these men are good, this is his horse". And in the plural, it can relate to the singular, as we say "this man is good, these are his cloaks".

\subsection{The treatment of government}

The section on 'government' starts with the construction of nouns governing the genitive. The author states that the most common use of this construction is to express possession, using the typically medieval mode of expression ex ui possessionis "by the force of possession". ${ }^{19} \mathrm{He}$ associates this usage with a more general rule, according to which "distributive, interrogative, and negative nouns as well as cardinal and ordinal numbers are construed with the genitive case or with the ablative with the preposition", ${ }^{20}$ such as quilibet istorum / quilibet ex istis "any of those". This rule invites comparison with Doctrinale vv. $1172-1173 .{ }^{21}$ The superlative is construed not only with the genitive, as in ego sum doctissimus hominum uel gentis uel populi uel turbe "I am the wisest of men or multitude or people or crowd", but also with the ablative, the accusative and with some individual prepositions, as in ego sum doctissimus inter socios "I am the wisest amongst the group"; however, the superlative of excellence is governed only by the genitive, as in flor das flores "the flower of the flowers" or rosa flos florum "rose the flower of the flowers" (cf. Doctrinale, v. 1186), senhor dos senhores "the lord of the lords" or domus domorum "the house of the houses" (Reglas ff. 76v-77v).

The dative is governed by verbs signifying benefit or loss, whereby the word signifying '(dis)advantage' is in the dative, as in este homé é a mï profeitoso, ou perciuil ou semelhauil ou uazio "this man is fruitful or perfidious or similar or empty to me" (ibid., f. 78r). ${ }^{22}$ The vocative is governed by the second person of the imperative of the verbs, which is either expressed or understood, as in o Petre, ueni uel o Petre omnes currunt "Peter, come or Peter, all are running" (ibid., f. 79r).

19. Cf. "Nomen significans possessum da genetiuo" (Doctrinale v. 1135).

20. "Nomina distributiua, interrogatiua, negatiua, numeralia, ordinalia construuntur cum genitiuis, uel cum ablatiuis, cum preposicione” (Reglas f. 77v).

21. Cf. "Cum partitiuis numerum seriemque locabis: 'quilibet, alter, uter, neuter, duo, quartus eorum"” (Doctrinale vv. 1172-1173).

22. "Diccio significans commodum uel incommodum construitur cum datiuo (ibid., f. 78r) "the word signifying an advantage or disadvantage is construed with the dative". Cf. Damnum significans aut utile pone datiuo (Doctrinale v. 1215). 
The discussion on the government of the ablative is the most elaborate, involving the following relations: excess, as in ego sum longior te quatuor palmis "I am four hands taller than you", ${ }^{23}$ price, as in panem numis tribus emi 'eu conprey este pam por dous dĩeyros' "I bought this bread for two coins", material, as in frenum fabricat ere 'eu faço huũ freo de ferro' "I make a brake of iron", cause, as in ista pudore silet este 'a'homẽ se cala per uergonha' "this woman is silent for reasons of shame", space, as in Çamora se perlonga Salamanca xii leguas "Zamora is twelve leagues away from Salamanca", and time (ibid., f. 79rv). ${ }^{24}$ Finally, the ablative also expresses 'maneyra de pronũciar' "manner of speaking", as in iste cantat submissa uoce "that man is singing in a low voice" (ibid., f. 79v). ${ }^{25}$

The account of the ablative is largely based on the Doctrinale vv. 1294-1295 and 1302-1308, but only once are verses from the Doctrinale quoted (see n.22), together with two examples. However, the Reglas usually introduces examples of its own. Its presentation of the government of the cases is considerably more concise than that in the Doctrinale.

\subsection{The treatment of 'transitivity'}

As compared with the Doctrinale (vv. 1369-1389), the Reglas pays little attention to the concept of transitivity, mentioning it only once (for transitivity, see, e.g., Kneepkens 1990b: 162-163, and Luhtala 2013, 2014). One of the rules states that transitive verbs whose verbal noun ends in -or / -trix are construed with the genitive, although the verb itself is construed with the accusative (Reglas f. 77r). This is one of the standard syntactical rules that can also be found in the Doctrinale vv. 1156-1159.

23. Cf. Est ablatiuus demonstrans, quantus habetur excessus; regit hunc excessum dictio signans (Doctrinale vv. 1294-1295).

24. The following verses are literally quoted in the Reglas f. 79v: "Verbum materiam, causam, spatium pretiumue aut tempus signans ablatiuos regit horum, quae praedicta notant, ut 'Frenum fabricat aere', 'ista pudore silet'; 'stadiis sex distat ab urbe'; 'nocte morans tota panem nummis tribus emit" "The verb signifying material, cause, space and price, or time, governs an ablative of the above mentioned, e.g., frenum fabricat ere "he makes a brake from copper", ista pudore silet "he is silent for shame", stadiis sex distat ab urbe "it is six stadiums distant from the city", and nocte morans tota panem nummis tribus emit "delaying all night, he bought bread with three coins" (Doctrinale vv. 1302-1304).

25. Cf. "Nomen eis adiunge, modum quod signat agendi: accentu plura proferre solemus acuto" (Doctrinale vv. 1307-1308). 


\section{Hic incipiunt notabilia que fecit cunctis}

The Notabilia is a highly complex codex of 89 folios (5r-93v), in paper and in quarto $(150 \mathrm{~mm} \times 212 \mathrm{~mm}$ ) format, from the National Library of Portugal, MS Alc. 79, ff. 5r-93v. It is dated September 1st, 1427, and has the signature of the Aragonese friar Juan Rodríguez de Caracena. It belonged to the Portuguese Cistercian Monastery of Alcobaça until 1834, when the Portuguese government suppressed the religious orders. It is written in gothic cursive handwriting by one or, more likely, by two copyists (see, e.g., Fernandes 2014: 185; 2017: 76). Only one chapter is dedicated explicitly and exclusively to syntax (De regimine, ff. $38 \mathrm{v}-44 \mathrm{r}$ ); however, all chapters include syntactical issues.

The Notabilia is intended to be studied at the highest level of instruction. Several authorities on medieval grammar are quoted, such as Alexander of Villa-Dei, Robert Kilwardby (Notabilia f. 68r), Peter Helias (ibid., f. 56r) and Priscian, as well as philosophers, such as Aristotle (384-322 B.C.) - see Fernandes (2017: 77-80). It also shows a number of speculative influences such as the definition of government: Regimen est debita et racionallis conjuncon in eadem clausula positarum ex modis significandi causata "Government is the coherent and rational conjunction of the words placed in the same sentence caused by the modes of signifying" (ibid., f. 87r; for the "modes of signifying" in Peter Helias, see Hunt 1980: 105-106). Among the unnamed sources of the Notabilia are probably the Catalan-Aragonese grammaticae proverbiandi $i^{26}$ and the Italian Giovanni da Soncino's (d. c.1363) Notabilia. In spite of its advanced nature, the Notabilia also makes use of pedagogical devices. The teaching material is organized into chapters of increasing difficulty, and the examples are often given both in Latin and Portuguese and sometimes only in the vernacular; they also involve several Spanish influences.

\subsection{Syntactical concepts in the Notabilia}

The term 'subject' (suppositum) is used only a few times in the Notabilia. Rodríguez de Caracena mainly uses the term 'nominative' for the subject of the sentence, as can be seen from the quotation below; in an active sentence it is described semantically as an agent (persona agens) and in the passive a patient (persona paciens): ${ }^{27}$

26. Regarding the Spanish grammatica prouerbiandi, see, e.g., Esparza Torres \& Calvo Fernández (1994) and Calvo Fernández $(1993,1995,2000)$, and for its presumed influence in the Notabilia, see Fernandes 2017: 80-83.

27. Concerning the notions of persona agens and persona patiens (the first and the second actants) in medieval Priscian commentators, see, e.g., Kneepkens 1990b and Fredborg 2014. 
Debes notare quod quocienscunque in oracione venerit persona agens et paciens [...], persona agens per actiuam est nominatiuus, et paciens accusatiuus [...]. Persona paciens per passiuam est nominatiuus et agens est ablatiuus cum preposicione 'de', 'a', uel 'ab'. (Notabilia f. 5r)

You should note that every time the agent or patient person [...] appears in the sentence, the agent person is nominative in the active, and the patient is accusative [...]. The patient person in the passive is nominative and the agent is ablative, with the preposition 'de', 'a', or 'ab'.

\section{2 'Concord' in the Notabilia}

In the Notabilia we do not find a list of concord rules, such as we find in the Reglas, but a comparable doctrine can be detected in various chapters. The agreement between the adjective and the substantive is described by saying that they agree in four accidents, case, gender, number, and government (Notabilia f. 27r), ${ }^{28}$ as in the Reglas. Several exceptions to this rule are then presented as well as eight modes of disagreement in number and case, caused mainly by three figures of construction: 'lepos', 'antiptosis', and 'prolepsis' (ibid., f. 82v). For instance, in the sentence ego uidi Petrum et Mariam albos "I saw the white Peter and Mary", 29 there is disagreement in gender and number: albos "white" (accusative plural masculine) does not agree in number with either of the nouns "Peter" and "Mary", which are each in the singular, and it also fails to agree in gender with "Mary", which is feminine.

Rodríguez de Caracena also mentions many other types of relations between the relative and its antecedent, such as, for instance, mutual, meditative, direct and indirect; all except the meditative relation were common in medieval grammars. ${ }^{30}$ The mutual relation is at issue when both the relative and its antecedent are expressed, whether they are in the same or a different case, as in Petrus legit qui currit "Peter, who runs, is reading" and Petrus currit cuius tedet me "Peter, who bothers me, is running" (Notabilia f. $74 \mathrm{v}$ ). In the former example, the relative qui and its antecedent Petrus agree in gender, number, person, and case. In the latter sentence, the relative does not agree in case with the antecedent, the antecedent Petrus being

28. "[...] adiectiuum debet conuenire cum suo substantiuo in quator actidentibus, scilicet, in casu in genere in numero et in regimine, ut 'Petrus albus currit"."

29. "Sexto modo disconueniunt in conceptione generum, uerbi gratia, 'ego uidi Petrum et Mariam albos', quia hoc quod dico 'albos' disconuenit cum substantiuo, scilicet Petrum et Mariam in numero cum Maria in genere” (ibid., f. 83r).

30. Indirect and direct relations are included in Peter Helias's Summa (ed. Reilly 1993: 909,9910,16). 
in the nominative and the relative cuius in the genitive. ${ }^{31}$ These two types are also identified as direct and indirect relatives, respectively (ibid., f. 75r). The meditative relation occurs when the relative is expressed and the antecedent is missing but easily understood in the mind (ibid.); here examples are missing.

As compared with the Reglas, the Notabilia presents a much more elaborate account of relative words, and many of the examples discussed pertain to figurative syntax. It is noteworthy that the pronoun qui, absent from the Reglas, plays a prominent part in the Notabilia. In fact, all the examples quoted in the Notabilia concern the pronoun qui, and the author points out that this pronoun has indeed many different uses (f. 78v). His list of relative words additionally include ego, suus, ipse, ille, is, and idem (f. 77rv).

\section{3 'Government' in the Notabilia}

Like the Reglas, the Notabilia discusses the relation between the subject and predicate in terms of government. Leaning on the authority of Peter Helias, Rodríguez de Caracena first argues that the verb governs the nominative and not the other way round, because the verb requires (exigit) the nominative, which is evident in Priscian. ${ }^{32}$ However, Priscian uses the verb exigere rather than regere (Inst. gram. XVII.133; GL III: 175.19; XVII.140, GL III: 178.12). Therefore, it seems that the author cites Priscian indirectly through Peter Helias. Almost at the end of the treatise, the author justifies this view by drawing on Priscian's doctrine, according to which the noun signifies a substance and the verbs the accidents of a substance:

[...] uerbum regit nominatiuum quia indiget eo et probatur sic: omne uerbum significat actidens (sic) et nomen significat substanciam et omne actidens [sic] indiget substanciam in qua fit. Ideo protanto $[s i c]$ nominatiuus regitur a uerbo quia indiget eo [...]. (Notabilia f. 86v)

$[\ldots]$ the verb governs the nominative because it needs it and the proof is as follows: every verb signifies accident and the noun signifies substance, and every accident needs substance, in which it inheres. Therefore, the nominative is governed by the verb because needs it $[\ldots]$.

31. See, e.g., Grammatica prouerbiandi edited by Calvo Fernández 1995 II: 44: "Relacionum, quedam est directa et quedam indirecta. Relacio directa est quando relatiuum et eius antecedens ponuntur in consimili casu, ut 'homo currit qui mouetur'. Sed relacio indirecta est quando relatiuum et eius antecedens ponuntur in diuersis casibus, ut 'homo currit quem diligo' et huiusmodi."

32. "[...] uerbum regit nominatiuum" (Notabilia f. 38v); "ergo uerbum regit nominatiuum et non eo contra, ectiam patet per Priscianum" (ibid., f. 43r). After a lengthy discussion pro and contra, Peter Helias comes to the conclusion that the verb governs the nominative: "Ideo verbum regit nominatiuum casum, nominatiuus vero non regit uerbum" (Summa II: 1050.92-1052.61). The same view is present in the Doctrinale v. 1081. 
The author then offers an argument supporting the opposite view: the noun governs the verb, because it is worthier than the verb:

[...] tamen contra hoc arguitur sic et probatur quod nomen regat uerbum et non uerbum nomen, et probatur sic: omne magis dignum debet regere minus dignum. Sed nomen est dignius quam uerbum, ergo nomen debet regere uerbum [...] (ibid.) $[\ldots]$ nevertheless, against this is argued and it is proven that the noun governs the verb and not the verb the noun; it is proven as follows: every more worthy must govern the less worthy, but the noun is worthier than the verb, therefore the noun should govern the verb $[\ldots]$.

He finds additional support for this view in Aristotle: the noun signifies a substance and the verb, an accident, and the cheapest substance is worthier than the noblest accident:

$[\ldots]$ nomen significat substanciam et uerbum significat actidens $[$ sic $]$ et $[\ldots]$ substancia est dignior actidente (sic), ut patet per Aristotilem dicentem: Villisima substancia nobilior est nobilisimo actidente [sic]. (ibid., ff. 86v-87r)

[...] the noun signifies substance and the verb signifies accident, and the substance is worthier than the accident, as is demonstrated by Aristotle who says: the vilest substance is worthier than the noblest accident.

Therefore, he concludes that the noun governs the verb; ${ }^{33}$ however, no sentence can be completed without the (accident of the) verb. ${ }^{34}$

\section{4 'Transitivity' in the Notabilia}

There are only a few references to transitivity in the Notabilia. Interestingly, one of these occurrences is in the only explicit quotation from the Catholicon (1286) of John of Genoa (d.1298). The author specifies that some "nouns derived from verbs like postulo 'to need' and posco 'to require' govern two genitives because of a double transition" (ibid., f. 6v). ${ }^{35}$ Posco and postulo are standard examples of verbs governing two accusatives in medieval grammar (see, for instance, Doctrinale v. 1265).

33. "[...] ergo nomen regit uerbum [...]; uerbum regit nomen et non nomen uerbum [...]" (ibid., f. $87 \mathrm{r})$.

34. "[...] nulla oratio perficitur sine uerborum actidens (sic) [...]" (ibid.).

35. "[...] uerbalia ab istis uerbis, 'postulo,' 'posco' et cetera, regunt duos genitiuos casus, dupplicis transicionis causa secundum Catholicum [...]”. 


\section{Grammatica of Juan de Pastrana}

The Grammatica Pastrane, also known by its incipit Thesaurus pauperum siue speculum puerorum, is the first grammar known to have been printed in Portugal. It was printed in 1497 by the German printer Valentin Ferdinand of Moravia or Valentim Fernandes (fl.1450-1519). This elementary manual, designed to be used during the first stages of language teaching, is an adaptation for Portuguese students from a grammar formerly written for Spanish schoolboys. ${ }^{36}$ It was edited by the Portuguese scholar Pedro Rombo (d.1533) and assembled with two other grammatical treatises composed by himself and António Martins (fl.1442), his predecessor as the teacher of the 'new Latin grammar' at the University of Lisbon (Verdelho 1995: 90-97). Pastrana's Grammatica constitutes the first part of the volume, having been printed before the others (see Anselmo 1979/80: 180), which were dedicated to the higher levels of teaching. ${ }^{37}$

The work is based on the medieval division of grammar into four parts, 'ortographia', 'prosodia,' 'ethimologia', and 'diasintastica', and its general approach is also distinctly medieval. The diasintastica - the section on syntax - is a compound of two parts, one on government 'de regimine' (Grammatica d ii v-d v v) and the other on construction 'de constructione' ( $\mathrm{d} \mathrm{v} \mathrm{v}-\mathrm{d}$ vi r). This corresponds to the division of the syntactical section in the Doctrinale. ${ }^{38}$ This textbook had strong opponents, including Elio Antonio de Nebrija (1441/1444?-1522) in Spain and Estêvão Cavaleiro (c.1460-1518) in Portugal. However, these antagonisms had to do with personal conflicts rather than linguistic or pedagogical issues (see Ramalho 1977/78, Sánchez Salor 2002).

Pastrana's Grammatica is the only one of these three treatises that uses visual aids in language teaching. These two elaborate trees summarize many basic syntactical concepts, such as the division of constructions into transitive and intransitive, and their components, persona agens and patiens:

36. For the other copies of Pastrana’s grammar until 1545, see Codoñer 2000: 39-43.

37. Concerning the other grammars of this compilation, namely by Pedro Rombo Materiarum editio ex baculo cecorum a Petro Rombo in artibus baccalario breviter collecta incipit and António Martins Materierum editio a baculo cecorum breviter collecta incipit, and their influence on Fernando Nepote's (fl.1460-1492) grammar Super arte et compendio doctissimi domini magistri Iohannis de Pastrane Materies, see Ponce León Romeo 2014.

38. The first part is contained in Chapter VIII, vv. 1074-1230 (regimen), and the second in Chapter IX, vv. 1369-1549 (constructio). 


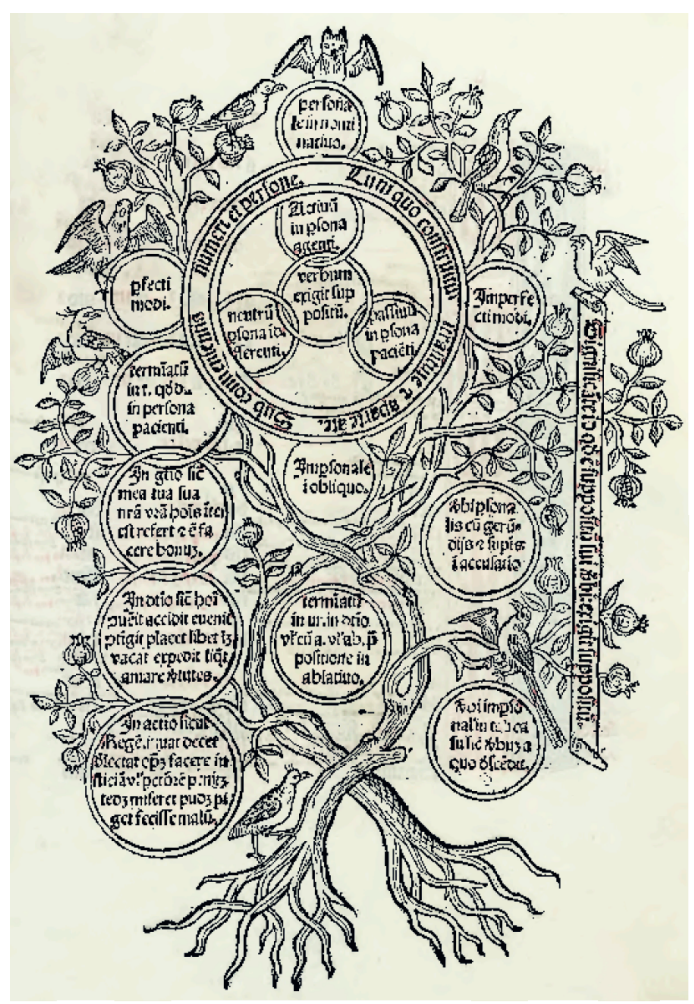

Figure 1: a vi r

\subsection{Syntactical Concepts in Pastrana's Grammatica}

The Grammatica opens with the section on ethimologia, which consists of the definitions of the parts of speech and a detailed account of their morphology. Immediately after listing the parts of speech, the nominal cases are introduced in semantic and functional terms, using the vernacular and following an approach very similar to that of the Reglas. This regula casuum "rule of cases" is the only context in which the vernacular is used in this elementary treatise:

Quem he ou quem faz nominatiuo. Cuja a cousa he genitiuo. A quem veẽ dãno ou proueyto datiuo. O que fazemos ou amamos acusatiuo. Per vocatĩuo chamamos. De quẽ, por quẽ, cõ quẽ, sem quem, em quem ablatiuo. (Grammatica a ii r)

Who is or who does is nominative. Whose the thing is, genitive. To whom they give damage or advantage, dative. What we do or we love, accusative. By vocative we call. From whom, by whom, with whom, without whom, in whom, ablative.

Although the textbook has a separate section on syntax, some basic syntactical concepts are introduced in the ethimologia. They include - in addition to the 


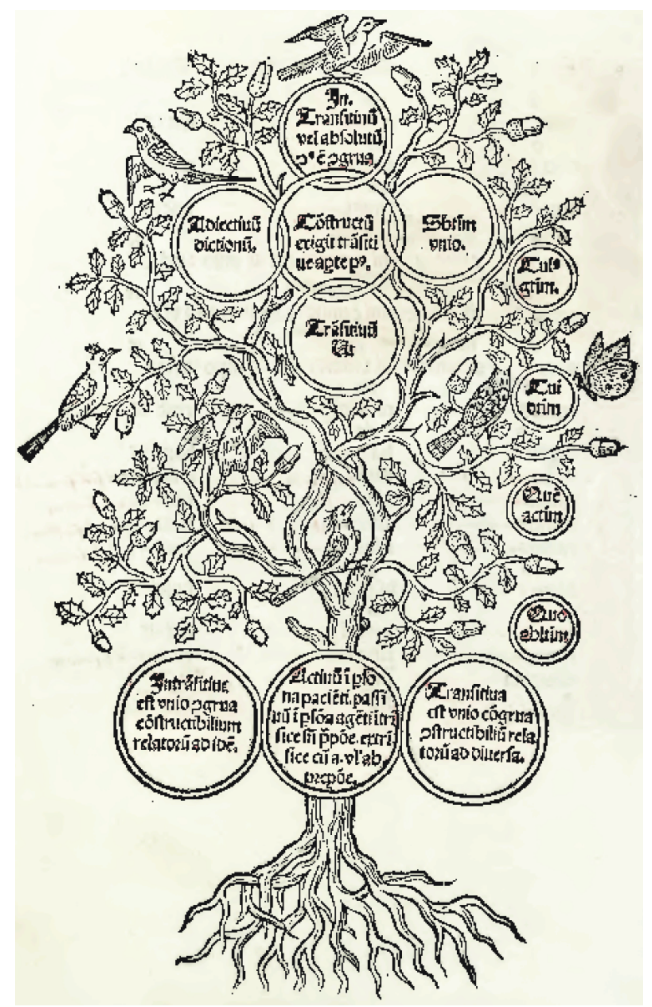

Figure 2: a vii v

above rule of cases - for instance the definition of the subject (suppositum) and the three concords. It is stated in the marginal gloss that these belong to the easiest part of syntactical doctrine (Grammatica a ii v). ${ }^{39}$ Pastrana describes the basic sentence as consisting of a subject and a verb, using the term suppositum for the subject, besides the 'nominative case'; the term appositum is not used in this treatise. The term 'subjectum' is used once (Grammatica d v v). The subject is defined as "the nominal word from whose meaning the action of the verb is affirmed or denied to arise" (Suppositum est dictio nominalis de cuius significato affirmatur uel negatur egredi actus uerbi). Here the relation between the subject and the verb is discussed in terms of agreement, constituting the first of the three concords that we encountered in the Reglas:

39. "Et in tractando de ethimologia inserit aliquas regulas diasyntastice ratione facilioris doctrine" (a ii v in the margin). This gloss is by Pedro Rombo. 
Suppositum et uerbum conueniunt in duobus, scilicet in numero et in persona. Substantiuum et adiectiuum conueniunt in tribus, scilicet in casu, in genere, et in numero. Relatiuum et antecedens conueniunt in tribus, in genere in numero et in persona.

The subject and predicate agree in two things, viz. in number and person. The substantive and the adjective agree in three things, viz. in case, gender, and number. The relative word and its antecedent agree in three things, viz. in gender, number, and person.

In Figure 1 Pastrana makes it explicit that "the verb requires the subject" (uerbum exigit suppositum) (a vi r).

It is also in the ethimologia section that Pastrana's definition of syntax can be found, being described in terms of constructions: Diasyntastica est ars qua constructiones dictionum cognoscuntur "Diasyntastica is an art by means of which constructions of words are identified." The construction is defined by Pastrana as a coherent union of words (ibid., $\mathrm{d} \mathrm{v} \mathrm{v}$ ), ${ }^{40}$ which is divided into transitive and intransitive. The intransitive construction is a coherent union of various words belonging to the same referent, which has three subtypes, as based on number, case, and gender, respectively. ${ }^{41}$ The transitive syntax is a coherent union of different words belonging to different referents, like lego lectionem "I read the lesson", of which there are two subtypes, active and passive. ${ }^{42}$ Pastrana describes (in)transitivity in terms of one or two referents involved in a construction, which was one of the standard ways of defining transitivity in the Middle Ages, being ultimately based on Priscian (e.g., Inst. gram. XVIII.5, GL III: 211.22-23). ${ }^{43}$ These concepts are also spelt out in Figure. 2.

\subsection{Pastrana's treatment of 'construction'}

The three syntactic relations known as the three concords occur twice in Pastrana's grammar. They are discussed among the easier syntactic doctrine in the ethimologia, being defined in terms of agreement. In the section on construction they are described as species of intransitive constructions involving number, case,

40. “[...] unio congrua dictionum [...]" (Grammatica d v v).

41. "[...] unio congrua diuersarum dictionum pertinentium ad idem cuius sunt tres species, scilicet numerus, casus et genus” (ibid., d v v).

42. "[...] unio congrua diuersarum dictionum pertinentium ad diuersa, ut 'lego lectionem', cuius sunt due species, scilicet actio et passio" (ibid., d vi r).

43. Martin of Dacia (1250/60-1304) has almost similar definitions: "Constructio intransitiva est in qua dictiones positae pertinent ad eandem personam uel ut ad eandem" (Martinus Dacus 116.11); "Constructio enim transitiva est in qua omnes dictiones positae pertinent ad diversas personas uel ut ad diversas personas" (Martinus Dacus 116.15; quoted in Kelly 2002: 165). 
and gender respectively (Grammatica $\mathrm{d} v \mathrm{v}$ ); here they represent, presumably, more advanced doctrine. Importantly, the author states that it is sufficient for the students to know these three species of intransitive constructions: "Et hoc de constructione intransitiua [sufficiat]" (ibid., d vi r, see Codoñer 2000: 66).

The intransitive construction of number (constructio intransitiua numeri) is defined as a coherent union of words, belonging to the same number, such as the subject and the verb (Grammatica d v v). ${ }^{44}$ The correct ordering demands that the subject is construed before the verb (ibid.). ${ }^{45}$ This rule applies to all clauses, except those starting with the vocative, the ablative absolute, and impersonal verbs (ibid.). In these cases, the sentence begins with the verb rather than the subject. ${ }^{46}$ The second species is an intransitive construction of case (constructio intransitiua casus), which means that various words, that is, the substantives and the adjectives, agree in case. According to the correct order of construing a sentence, the substantive comes first, followed by the adjective, according to the rule: "[...] every substantive is construed first, then its adjective, or at the same time [...]" 47 (ibid., $\mathrm{d}$ vi r). Here, Pastrana fails to mention the agreement in gender and number, whereas the concord of the relative pronoun and its antecedent is only said to involve gender. The third species of intransitive construction is indeed termed an intransitive construction of gender (constructio intransitiua generis). For instance, in the sentence Magister legit qui non dormit (ibid.) "The scholar who does not sleep is reading", the masculine relative qui agrees with the masculine noun magister. The antecedent should be construed before the relative, by the rule: "[...] every antecedent is construed first, then its relative $[\ldots]$ ". 48

\section{3 'Government' in Pastrana's Grammar}

The chapter on government contains a large number of rules explaining the construction of nouns and verbs with the various cases, covering six pages. The chapters are organized according to the cases which are governed, following their traditional order, starting with the nominative and finishing with the ablative. The terms used in describing the syntactic relations are regere "to govern", exigere "to demand", and construi "to be construed".

44. "De prima specie quod constructio intransitiua numeri est unio congrua [diuersarum] dictionum pertinentium ad eundem numerum, cuiusmodi sunt suppositum et uerbum."

45. "[...] semper incipitur constructio a supposito prius quam a uerbo [...]"

46. "[...] in talibus non incipitur constructio a supposito, sed a uerbo."

47. "[...] omne substantiuum est prius construendum quam suum adiectiuum uel simul."

48. “[ $\ldots]$ omne antecedens est prius construendum quam suum relatiuum [...]” (ibid.). 
Pastrana starts the chapter on government (Grammatica $\mathrm{d}$ ii v) by presenting the subject / predicate relation in terms of intransitivity and concord rather than government, using the terms 'nominative case' and 'personal verb'; he additionally resorts to the medieval notion of a natural word order, whereby the subject precedes the verb.

Omnis rectus intransitive est constructibilis cum uerbo personali a parte ante uel a parte post per naturam suppositi vel idempitatis suppositi, ut 'domine tu es bonitas eterna'. (ibid., d ii v)

Any direct case can be construed intransitively with a personal verb placed either before or after it by the force of the subject or the identity of the supposite, e.g. 'Lord, you are eternal goodness'. ${ }^{49}$

After explaining the concord of the subject and the predicate, the author goes on to deal with cases, in which the constituents lack concord. He presents a rule, according to which a noun in the third person can be joined intransitively to a first or second person of a noun or a verb, when a first or second person pronoun is also present:

Omne nomen tertie persone debite iunctum intransitiue prime uel secunde persone nominis uel uerbi reddit suppositum in prima uel secunda persona, ut 'tu Petrus disputas dum ego et Iohannes currimus'. (ibid., d ii v)

Whenever a noun of the third person is properly joined intransitively with the first and the second person of the noun [pronoun] or the verb, the subject is in the first or the second person, like tu Petrus disputas dum ego et Iohannes currimus "you, Peter, argue while I and John run".

When a third person noun Petrus is joined intransitively to a first or second person pronoun tu or ego, as in $t u$ Petrus, the verb is either in the first or the second person, respectively, as in tu Petrus disputas "you, Peter are disputing" - here tu is joined intransitively to Petrus and the verb disputas is in the second person -, whereas in dum ego et Iohannes currimus the first person ego is joined to the third person Iohannes intransitively, and the verb currimus is in the first person plural. However, the sentence is incongruous when a noun is joined to a verb in the first or second person, as in Petrus oro or oras "Peter I pray" or "Peter you pray", while no second or first person pronoun is present, whereas Petrus orat "Peter is praying" is congruent (ibid., $\mathrm{d}$ iii $\mathrm{r}$ ).

Pastrana presents rules on transitive construction involving the government of nouns, adjectives, verbs, and adverbs, depending heavily on the Doctrinale, but

49. This rule also covers a sentence with a copula, as in the example. 
without adopting its examples. To each type of relation, the author dedicates a separate, though short, chapter. For example, the genitive is governed by nouns signifying identity, as in uerbum Dei "word of God"; totality, as in angelus bone uoluntatis "the messenger of the good will"; part (v. 1146), as in planeta celi "the planet of the heaven"; possession (v. 1135), as in homo dei "man of God"; continent (v. 1149), as in dolium uini "barrel of wine"; content (v. 1148), as in cerebrum capitis "the brain of the head"; excellence (v. 1186), as in flos florum "the flower of the flowers"; superlative (v. 1178-1179), as in rex est fortissimus militum "the king is the strongest of the soldiers"; price (v. 1301), as in equus mille solidorum "the horse of a thousand ducats"; age (v. 1188), as in puer octo annorum "an eight year old boy"; measure (v. 1300), as in uas trium modiorum "vessel of three bushels"; relationships (vv.1152-1155), as in pater filii "father of the son"; property or habits, as in the verbal nouns ending in -tor, -trix (vv. 1156-1158), -tivus, -ns (present participle), -tus, -idus, -scius, -rus, -ax; cardinal and ordinal numbers (vv. 1172-1173); universals and particulars; interrogative, demonstrative, and negative pronouns (v. 1173); and collective nouns (Grammatica d iii r).

\subsection{Pastrana's discusson of 'transitivity'}

In Pastrana's textbook, the intransitive construction is related to concord and the transitive to government. The primary distinction of the transitive construction is between active and passive (Grammatica d vi r), but transitivity is not restricted to active sentences involving the nominative and the accusative case and its passive equivalent, respectively. In his classification, active verbs govern transitively even the genitive, dative and ablative, as well as mixed cases like the double accusative. For instance, the active verbs egeo "to need", indigeo "to need", careo "to lack" and habundo "to grow abundantly" are construed transitively with genitives or ablatives, as in minoritas eget vel indiget maioritatis "the minority needs the majority", ${ }^{50}$ or other verbs which are construed transitively with the dative in the patient person (ibid.). ${ }^{51}$

Furthermore, transitivity is not restricted to nouns and verbs in Pastrana's grammar. For instance, adverbs demand specific cases transitively, such as magis "more", satis "enough", plus "plus" (genitive or ablative), ad "to", apud "in", ante "ahead" (accusative), in "in", sub "under", super "above" (accusative or ablative), $a$, $a b, a b s$ "from" (ablative), and so forth (Grammatica d v r).

50. "[...] construuntur transitiue cum genitiuis uel ablatiuis, ut minoritas eget uel indiget maioritatis uel maioritate [...]” (ibid. d iv r).

51. “[...] construuntur transitiue cum datiuis in persona pacienti [...]" (ibid.). 


\section{Conclusions}

In the 13th century, a distinction was drawn between practical and speculative grammar, but the division between pedagogical and theoretical grammar in the Middle Ages was not an absolute one. ${ }^{52}$ This is true especially of the study of syntax, which was developed in close association with logic. For instance, the concepts of subject and predicate, which were first adopted from logic into the more advanced works of grammar in the 12th century, were soon also transferred into more elementary grammars, appearing for example in the Doctrinale. The three Portuguese treatises scrutinized in this essay permit us to examine how basic syntactical doctrine was introduced at the elementary, intermediate and advanced levels of instruction in the late Middle Ages.

The most elementary of these textbooks, the Grammatica of Juan de Pastrana, depends heavily on the Doctrinale for its syntactical doctrine. It is probably from the Doctrinale that Pastrana had adopted the division of syntactical theory into government and construction, associating government with transitive construction and concord with intransitive construction. Importantly, the Grammatica also provides methodical definitions of all these constructions. Like the Doctrinale, it makes regular use of the concept of transitivity in analyzing verb and noun phrases as well as the syntax of adverbs, defining (in)transitive constructions semantically as pertaining to one or two referents, respectively (cf. Doctrinale vv. 1369-1373). Furthermore, most of Pastrana's rules of government depend directly or indirectly on the Doctrinale; however, the examples are mostly his own. From a source more recent than the Doctrinale, Pastrana has adopted the three concords, ${ }^{53}$ introducing them among the more elementary syntactical doctrine in the section on ethimologia. Considering that this textbook, printed in 1497, represents 'new learning', its doctrine is strikingly medieval: it follows the medieval quadripartite division of grammar and uses a wide selection of medieval tools of syntactical analysis, providing methodical definitions for these concepts.

The Doctrinale was also an important source for the syntactical doctrine of the Reglas, and its sources similarly include a more recent work, from which it had adopted the three concords. However, the approach of the Reglas is less methodical than that of Pastrana's Grammatica. This textbook follows no particular grammatical order in its exposition and it generally fails to define grammatical concepts. It

52. According to Rosier-Catach (2010: 203), "the division between didactic and theoretical grammar cannot be seen as an abolute one" and "didactic grammars of the turn of the twelfth and thirteenth century were not totally separated from the new orientations that grammar develops with the rise of the universities".

53. This source was probably either a late medieval Regule-text or any other late medieval textbook transmitting similar doctrine. 
makes a less frequent use of technical terms in describing grammatical phenomena: the term used for agreement is 'to be similar', and a sentence is described as consisting of a nominative case and a verb rather than a subject and a predicate. Moreover, several syntactical rules are frequently combined into one. It is possible to interpret these as signs of shortening and simplifying grammatical doctrine. This tendency sometimes results in obscurity, which is the case when the relative pronoun qui is absent from the discussion on relative words.

Since the Reglas has no paradigms, it is fair to assume that it was not the first Latin grammar in the pupils' curriculum. Indeed, it was probably intended to be studied at an intermediate level, like the Doctrinale. The Reglas depends on the Doctrinale for its theory of government, but the Doctrinale treats the issue in much more detail than the Reglas. Moreover, the Doctrinale quotes several exceptions to the basic grammatical rules whereas the Reglas fails to quote any exceptions to the rules. For instance, the discussion on the relation between an adjective and its headword in the Doctrinale is followed by 37 lines presenting exceptions caused by the figure of conception (vv. 1093-1130). Thus, it appears that the late medieval standards of grammar teaching as represented by the Reglas are different from those of the early 13 th century.

Consistent with its advanced nature, the grammar of Rodriquez de Caracena discusses syntactical issues in much more detail than the more elementary grammars. As regards the relation between an adjective and its headword, several exceptions to the basic rule are given, as well as eight modes of disagreement in number and case, caused mainly by figures of constructions. The Notabilia also has an elaborate account of the relative pronouns, in which different types of relations are recognized and exceptional uses are explained by resorting to figurative syntax. The author provides arguments for and against the view that the verb governs the noun in a nuclear sentence. Such arguments are not present in the more elementary textbooks.

Concord and government are the basic tools of syntactical analysis in all the three treatises, whereas transitivity has lost its central role in describing grammatical relations, occurring only in Pastrana's Grammatica. As regards government, all treatises use the regular medieval terminology of regimen "government" in describing syntactical rules, but the verbs exigere "to require" and construi "to be construed with" are equally popular. All textbooks mention the term suppositum, but only Pastrana defines it and makes more regular use of it when referring to the subject of a sentence; the others prefer the nominative case. The term appositum is not used in any of the textbooks. The relation between the subject and predicate is described in terms of government in the Reglas and the Notabilia, and in terms of concord and transitivity in Pastrana's Grammatica. In the Reglas the verb governs the nominative (cf. Doctrinale v. 1081), whereas de Caracena comes to the conclusion that it is the noun that governs the verb. 
The use of the vernacular is attested in all three treatises. The Reglas was written in Romance with examples in Latin, and the Notabilia was written in Latin with examples translated into Romance languages (Portuguese and Spanish). Although Pastrana's Grammatica uses Portuguese only once, it seems fair to conclude that the use of the mother tongue of the students in the classes was common at the various levels of teaching in Portugal from the 14th century onwards.

\section{ACKNOWLEDGEMENTS}

I would like to dedicate this paper to the memory of Prof. Amadeu Rodrigues Torres (19242012). I also want to acknowledge the help of Profs. Rolf Kemmler (UTAD, Portugal) and Mónica Augusto (independent scholar, Portugal) in the transcription of the Reglas and the Notabilia, and Prof. Vicente Calvo Fernández (URJC, Spain) in solving various abbreviations, mainly in the Notabilia. Furthermore, I would like to thank Dr Anneli Luhtala (University of Helsinki, Finland) for her support, suggestions, and instructions, and the three anonymous referees, whose considerations and improvements I have tried to implement in the latest version of this paper. I would also like to acknowledge the support of Prof. Carlos Assunção (UTAD, Portugal), who, as Director of the Center for the Studies in Letters (CEL), has funded this research, under the reference UID/LIN/00707/2016 from the Portuguese Foundation for Science and Technology (FCT).

\section{REFERENCES}

\section{A. Primary sources}

Alexander de Villa-Dei. Das Doctrinale des Alexander de Villa-Dei. Kritisch-exegetische Ausgabe by Dietrich Reichling. Berlin: A. Hofmann, 1845 (Repr., New York: Burt Franklin, 1974.)

Arte de Prisciano y Castellano. Madrid, the Spanish National Library, MS 10073.

$G L=$ Grammatici Latini. Ed. by Heinrich Keil. 8 vols. Leipzig: B. G. Teubner, 1855-1880. (Repr., Hildesheim: Georg Olms, 1981.)

Grammatica Proverbiandi. See Vicente Calvo Fernández. 1995, Part II, 1-365.

Pastrana, Juan de. 1497. Grammatica Pastrane. Incipit compendium breue et utile: Siue tractatus intitulatus: Thesaurus pauperum siue speculum puerorum editum a magistro Johanne de. Ulixbone: Impressum per Valentinum Fernandi de Moravia. MS Lisbon, National Library of Portugal, INC 1425. http://purl.pt/22005. (Last accessed: 20 January 2017.)

Peter Helias. Summa super Priscianum. Ed. by Leo Reilly. 2 vols. Toronto: Pontifical Institute of Mediaeval Studies, 1993.

Priscian. Prisciani Grammatici Caesariensis Institutionum Grammaticarum libri XVIII. Ed. by Martin Hertz $=$ GL 2-3.

Reglas = Anonymous. Reglas pera enformarmos os menỹos en latin. MS Oxford, Bodleian Library, Digby 26, ff. 76r-82v.

Remigius, Schleswig 1486. A Latin Grammar in Facsimile Edition with a Postscript by Jan Pinborg. Copenhagen: Royal Danish Academy of Sciences and Letters, 1982. 
Rodríguez de Caracena, Juan. 1427. Hic incipiunt notabilia que fecit cunctis (= Notabilia). MS Lisbon, National Library of Portugal, Alc. 79, ff. 5r-93v. http://purl.pt/24440. (Last accessed 20 January 2017.)

Tre Latinske Grammatiker, Donatus, Fundamentum, Regulae. Ed. by Jan Pinborg \& Erik Dal. Copenhagen: Munksgaard, 1979.

\section{B. Secondary sources}

Anselmo, Artur. 1979/1980. "Incunábulos Portugueses em Latim (1494-1500)". Humanitas 31/32.167-196.

Barreto, Manuel Saraiva. 1985. “Os 'Notabilia' gramaticais alcobacenses”. Euphrosyne Nova Série 13.79-94.

Barreto, Manuel Saraiva. 1988. "Antecedentes medievais da gramática renascentista”. O Humanismo Português: 1500-1600. Primeiro Simpósio Nacional, 21-25 de Outubro de 1985 ed. by José Vitorino de Pina Martins et al., 163-175. Lisboa: Academia das Ciências de Lisboa.

BS = Biblia Sacra Juxta Vulgatam Clementinam. 2005. Electronic edition by Michaele Tvveedale. London. http://www.wilbourhall.org/pdfs/vulgate.pdf. (Last accessed: 13 February 2017.)

Calvo Fernández, Vicente \& Miguel Ángel Esparza Torres. 1999. "El 'Arte de Prisciano y Castellano': una gramática medieval con glosas romances”. Romanistik in Geschichte und Gegenwart 5:2.135-158.

Calvo Fernández, Vicente. 1993. "Un ejemplo de empleo del romance en la didáctica del latín medieval: la traducción de participios en la Gramática de Prisciano y castellano”. Revista de Filología Románica 10.267-283.

Calvo Fernández, Vicente. 1995. Grammatica proverbiandi: la enseñanza del latín en la baja edad media española: estudio y edición del texto contenido en el ms. 8950 de la Biblioteca Nacional de Madrid. Doctoral Thesis. Madrid: Universidad Complutense de Madrid. http://eprints. ucm.es/3374. (Last accessed: 17 February 2017.)

Calvo Fernández, Vicente. 2000. Grammatica Proverbiandi. Estudio de la Gramática Latina en la Baja Edad Media Española. Münster: Nodus.

Codoñer, Carmen. 2000. Gramáticas Latinas de Transición: Juan de Pastrana y Fernando Nepote. Introducción y Edición Crítica. Salamanca: Ediciones Universidad de Salamanca.

Esparza Torres, Miguel Ángel \& Vicente Calvo Fernández. 1994. "La grammatica proverbiandi y la nova ratio nebrissensis”. Historiographia Linguistica 21:1/2.39-64. doi:10.1075/hl.21.1-2.03esp

Fernandes, Gonçalo. 2010. "Reglas para enformarmos os menỹos en latin (MS. séc. XIV)". Ideias Linguísticas na Península Ibérica (séc. XIV a séc. XIX). Projeção da Linguística Ibérica na América Latina e Ásia, vol. 1, ed. by Carlos Assunção et al., 223-236. Münster: Nodus.

Fernandes, Gonçalo. 2013. "Vernacular and language teaching in the Portuguese Middle Ages: The MS. Digby 26 and the Reglas para enformarmos os menỹos en latim". Beiträge zur Geschichte der Sprachwissenschaft 23:1.55-70.

Fernandes, Gonçalo. 2014. "Gramática especulativa medieval em Portugal: Os Notabilia alcobacenses”. Métodos y Resultados Actuales en Historiografía de la Lingüística, vol. I, ed. by María Luisa Calero Vaquero et al., 183-192. Münster: Nodus.

Fernandes, Gonçalo. 2017. "Sources of the Notabilia (1427): A medieval handwritten grammatical treatise from the Portuguese monastery of Alcobaça”. Folia Linguistica Historica 38.75-89.

Fredborg, Karin Margareta. 2014. "Medieval Commentators on the Notion 'persona agentis' in Priscian’s Syntactic Theory”. Historiographia Linguistica 41:2/3.219-245.

doi: 10.1075/hl.41.2-3.02fre 
Gómez Moreno, Ángel. 1989. “Grammatica Castellana de Palácio: Un nuncio de Nebrija”. Revista de Literatura Medieval 1.41-51.

Hunt, R[chard]. W. 1980. Collected Papers on the History of Grammar in the Middle Ages. Edited with an introduction, a selected bibliography and indices by G. L. Bursill-Hall (= Studies in the History of Linguistics, 5.) Amsterdam: John Benjamins. doi:10.1075/sihols.5

Kelly, L[ouis]. G. 2002. The Mirror of Grammar: Theology, Philosophy and the Modistae. (= Studies in the History of Linguistics, 101.) Amsterdam \& Philadelphia: John Benjamins. doi: 10.1075/sihols.101

Kneepkens, Corneille Henri. 1990a. “On Mediaeval Syntactic Thought with Special Reference to the Notion of Construction”. Histoire Épistémologie Langage 12:2.139-176 doi:10.3406/hel.1990.2321.

Kneepkens, Corneille Henri. 1990b. “Transitivity, Intransitivity and Related Concepts in 12th Century Grammar: An explorative study”. De Ortu Grammaticae: Studies in Medieval Grammar and Linguistic Theory in Memory of Jan Pinborg ed. by G. L. Bursill-Hall, Sten Ebbesen \& Konrad Koerner, 161-189 (= Studies in the History of Linguistics, 43.) Amsterdam \& Philadelphia: John Benjamins. doi:10.1075/sihols.43.12kne

Law, Vivien A. 1994. 'Grammar'. Carolingian Culture: Emulation and innovation ed. by Rosamund McKitterick, 88-110. Cambridge: Cambridge University Press.

Law, Vivien A. 2003. The History of Linguistics in Europe: From Plato to 1600. Cambridge: Cambridge University Press. doi:10.1017/CBO9781316036464

Lozano Guillén, Carmen. 1995. "Juan de Pastrana y su singular clasificación de la dictio dentro de la gramática del S. XV”. Minerva 9.187-196.

Luhtala, Anneli. 1993. "Syntax and Dialectic in Carolingian Commentaries on Priscian's Institutiones grammaticae". History of Linguistic Thought in the Early Middle Ages ed. by Vivien A. Law, 145-191 (= Studies in the History of the Language Sciences, 71.) Amsterdam \& Philadelphia: John Benjamins. doi:10.1075/sihols.71.08luh

Luhtala, Anneli. 2013. "Pedagogical grammars before the eighteenth century". The Oxford Handbook of the History of Linguistics ed. by Keith Allan, 341-358. Oxford: Oxford University Press.

Luhtala, Anneli. 2014. "Scholastic Influence on Syntactical Theory in Pedagogical Grammars". Beiträge zur Geschichte der Sprachwissenschaft 24:1.51-70.

Luhtala, Anneli. 2017 in press. “Teaching Agreement: A case study in the language pedagogy of three humanist treatises on syntax from Early Modern England". The History of Language Learning and Teaching I. 16th-18th Century ed. by Nicola McLelland \& Richard Smith. Cambridge: Legenda.

Marenbon, John. 1994. 'Carolingian Thought'. Carolingian Culture: Emulation and innovation ed. by Rosamund McKitterick, 171-192. Cambridge: Cambridge University Press.

Michael, Ian. 1970. English Grammatical Categories and the Tradition to 1800. Cambridge: Cambridge University Press.

Nascimento, Aires Augusto. 1989. "Pueris laica lingua reserabit: As 'Reglas pera enformarmos os menynos en Latin.' MS Oxford, BL, Digby 26 (séc. XIV)”. Euphrosyne Nova Série 17.209-232.

Percival, W. Keith. 1997. "Nebrija and the Medieval Grammatical Tradition". Antonio de Nebrija: Edad media y Renacimiento ed. by Carmen Codoñer \& Juan Antonio González Iglesias (= Acta Salmanticensia, Estudios Filológicos, 257), 247-257. Salamanca: Ediciones Universidad de Salamanca. 
Pérez Rodríguez, Estrella \& Carmen Lozano Guillén. 1988. “'Suppositum’ y 'appositum’ en la teoría sintáctica medieval y su proyección en el Renacimiento". Minerva: Revista de Filología Clásica 2.287-332.

Ponce de León Romeo, Rogelio. 2014. "Notas sobre la gramática escolar latinoportuguesa a inicios del siglo XVI: Los tratados de António Martins y Pedro Rombo". Métodos y resultados actuales en Historiografía de la Lingüística ed. by María Luisa Calero et al., 585-593. Münster: Nodus.

Ramalho, Américo da Costa. 1977-1978. “Um capítulo da história do humanismo em Portugal: O 'Prologus' de Estêvão Cavaleiro”. Humanitas 29/30.51-74.

Robins, R[obert]. H. 1980. "Functional Syntax in Medieval Europe". Studies in Medieval Linguistic Thought dedicated to Geoffrey L. Bursill-Hall ed. by E. F. Konrad Koerner, Hans-J. Niederehe \& R. H. Robins (= Studies in the History of Linguistics, 26), 231-240. Amsterdam \& Philadelphia: John Benjamins. doi:10.1075/sihols.26.18rob

Rosier, Irène. 1984. “Transitivité et ordre des mots chez les grammairiens médiévaux". Matériaux pour une histoire des theories linguistiques ed. by Sylvain Auroux et al., 181-189. Lille: PUL.

Rosier, Irène. 1994. "L'introduction des notions de sujet et de prédicat dans la grammaire médiévale". Archives et documents de la SHESL, 2e série 10.81-119.

Rosier-Catach, Irène. 2010. The Cambridge History of Medieval Philosophy ed. by Robert Pasnau \& Christina van Dyke, vol. I, 196-216. Cambridge: Cambridge University Press.

Sánchez Salor, Eustaquio. 2002. "Nebrija contra pastrana en el Portugal de 1500”. In Centro de Estudos Clássicos (ed.), Cataldo e André de Resende: Congresso Internacional do Humanismo Português (Coimbra, Lisboa, Évora, 25 a 29 de Outubro de 2000), 185-206. Lisboa: Centro de Estudos Clássicos.

Thomson, David. 1984. An Edition of the Middle English Grammatical Texts. New York \& London: Garland.

Verdelho, Telmo. 1995. As Origens da Gramaticografia e da Lexicografia Latino-Portuguesas. Aveiro: Instituto Nacional de Investigação Científica.

\section{SUMMARY}

This essay analyses the most central concepts of Latin syntactical theory in the earliest pedagogical grammars written in Portugal during the 14 th and 15 th centuries, namely concord, government, and transitivity. The sources include two unpublished treatises preserved in manuscripts of Portuguese origin, one from the end of the 14th century and the other dated 1427, and the first grammar printed in Portugal (1497). They are representative of the teaching of Latin in Portugal at different levels of learning. All three treatises use the vernacular as a pedagogical aid, and Pastrana's grammar also employs images to illustrate the main syntactical concepts. All treatises discuss government using the regular medieval terminology of regere "to govern" and regi "to be governed". Like in Spanish, Italian and English grammars of Latin, the three concords belong to the basic syntactical doctrine. The major difference between these textbooks lies in their employment of the concept of transitivity. It is little more than mentioned in the two manuscripts, but highly relevant in the printed grammar. 


\section{RÉSUMÉ}

Cet article analyse les concepts les plus importants de la théorie syntaxique latine dans les premiers traités pédagogiques grammaticaux écrits au Portugal au XIVe et XVe siècle, à savoir la concordance, la régence et la transitivité. Les sources de cette recherche sont deux manuscrits inédits d'origine portugaise (fin du XIVe siècle et 1427) et la première grammaire imprimée au Portugal (1497). Ils sont représentatifs de l'étude de la langue latine au Portugal pour les étudiants à différents stades. Les trois traités étudiés utilisent la langue vernaculaire et la grammaire de Pastrana offre des images pour systématiser les principaux concepts syntaxiques. Tous les auteurs utilisent la terminologie régulière médiévale de regere "gouverner" ou regi "être gouverné", et comme dans les grammaires espagnoles, italiennes et anglaises du latin, les trois concordances appartiennent à la doctrine syntaxique de base. La principale différence entre tous les traités étudiés réside dans le concept et le traitement de la transitivité. Il n'est guère mentionné dans les deux manuscrits, mais il y a une grande pertinence dans la grammaire imprimée.

\section{ZUSAMMENFASSUNG}

Dieser Forschungsbeitrag untersucht die wichtigsten Konzepte der lateinischen syntaktischen Theorie in den frühesten in Portugal geschriebenen pädagogischen Grammatiktraktaten für Bildungszwecke, die während des 14. und 15. Jahrhunderts geschrieben wurden, nämlich die der Konkordanz, der Rektion und der Transitivität. Untersucht werden zwei bislang unveröffentlichte Handschriften portugiesischer Herkunft (Ende des 14. Jahrhunderts bzw. 1427) sowie die erste in Portugal gedruckte Grammatik (1497). Diese Werke stehen für das Sprachstudium in Portugal für Schüler verschiedener Lernstufen. Alle drei analysierten Grammatiktraktaten verwenden die Volkssprache und Pastranas Grammatik greift auf Bilder zurück, um die wichtigsten syntaktischen Konzepte zu systematisieren. Alle Autoren verwenden den regelmäßigen mittelalterlichen Begriff regere "regieren" oder regi "regiert werden", und wie in spanischen, italienischen und englischen Lateingrammatiken gehören die drei Konkordanzen zur syntaktischen Grundtheorie. Der wesentliche Unterschied zwischen den drei Traktaten liegt im Konzept und in der Behandlung der Transitivität. Diese wird in beiden Handschriften kaum erwähnt, erhält aber eine hohe Bedeutung in der gedruckten Grammatik.

\section{Author's address}

Gonçalo Fernandes

Departemento de Letras, Arte e Comunicação

Universidade de Trás-os-Montes e Alto Douro

Centro de Estudos em Letras

PT-5001-801 VILA REAL

Portugal

gf@utad.pt 